\title{
Antecedents of Employee Loyalty With Reference To Job Satisfaction in Pump Manufacturing Industries-Coimbatore City
}

\author{
S.Annie Priyadharshini, J.Clement Sudhahar
}

\begin{abstract}
Coimbatore is among the most industrially developed and commercially vibrant districts in TamilNadu. There are about 600 pump manufacturing units and 400 supporting units (support of pump set Parts) in Coimbatore; it accounts for nearly $40 \%$ of the pump sets manufactured in India. Employees play a vital role in this regards. Most of the organization wants to retain the talented employees in the organization, in the same way employees join the organization with various expectations and job needs. Various studies showed that job dissatisfaction leads to employee turnover absenteeism etc.The present study made an attempt to examine the relationship between job satisfaction and employee loyalty in pump manufacturing industries in Coimbatore region.
\end{abstract}

Keywords: employee loyalty, organization Success Organization success, Job Performance

\section{INTRODUCTION}

The term employee loyalty explains about how happy the employees are with the organisation and also explains the reason for staying in the organisation. In today's competitive Business environment the organisation success is based on the performance of the employees and hence Retaining Knowledge employees or qualified, skilled employees are essential for the sustainability of an organization. Many research studies explained employee loyalty as an important factor which influences the employee's behaviour and mostly explained under the factors such as "organizational commitment, Job satisfaction and Employees Trust, Leadership style, Motivation, organisational Justice or support and employee-employer Relationship. Several studies showed that that employee loyalty is positively influenced by these factors also employee loyalty has some link with the concepts such as absenteeism, organisational citizenship and turn over intentions. In organisation behaviour context the terms organizational commitment and Employee Loyalty are studied by many researchers and stated that both talks about the employees behaviour and the reasons to stay in the particular organisation, there is no difference between the two terms. The present research attempt to investigate and analyze the antecedents of employee loyalty With Reference to job satisfaction in Pump Industries, Coimbatore.

Revised Manuscript Received on November 08, 2019.

* Correspondence Author

S.Annie priyadharshini, Research Scholar,Department of Management, Karunya Institute of technology and Sciences, Coimbatore, Email: annieresearch2019@gmail.com

J.Clement Sudhahar, Associate Professor , Department of Management, Karunya Institute of technology and Sciences, Coimbatore, Email: Clement@karunya.edu

\section{REVIEW OF LITERATURE}

(Mai Khuong et al., 2015) wants to identify the relationship between job satisfaction and organizational loyalty of employees who are working in the banking industry in Ho Chi Minh City (HCMC). The sample size of the study was 201 full time employees who are working in 11 banks in HCMC.The study revealed the factors of employee loyalty are employee job satisfaction, working environment team support and work environment. The study also suggested that the organization and managers should assign priority to these factors because it will lead to higher level of employee loyalty.

(Chetna Pandey et.al.,2012) investigated 100 employees from manufacturing and 100 from service industry in Gwalior Region to find out the impact of job satisfaction and organizational Commitment on employee loyalty and also to study the relationship between job satisfaction and organizational commitment. The final result of the study says there is significant difference in loyalty exist between the employees of manufacturing and service industry. Further there is a relationship between job satisfaction and organization commitment. At last the factors of loyalty from this study are commitment, motivation, belongingness and career development.

Ramanathan and Senthil 2013 conducted the research in South Indian states with 100 samples. The purpose of the research is to explore the different facets of employee loyalty in equipment rental business and also to identify the most essential factors influencing employee loyalty. The findings of the study suggested that equipment rental business should pay more attention to improve employee loyalty in personal benefits, work environment, leadership style.

(Seema Mehta et al., 2010) The objective of the study was to find out the employee loyalty towards organization among professional and non-professional teachers and to explore the underlying factors of loyalty. The factors of loyalty found from this study are career development, motivation, bonding, job security, leadership, and commitment. The sample size was 100 teachers of various professional and non-professional institutions of Gwalior region.

\section{RESEARCH OBJECTIVES}

- The present research attempts to investigate the antecedents of employee loyalty in various pump manufacturing industries in Coimbatore. 


\section{Antecedents of Employee Loyalty With Reference To Job Satisfaction in Pump Manufacturing Industries-Coimbatore City}

- The examine the relationship and influence of employee loyalty and job satisfaction with the reference to various factors of the study

- To find out the relationship between employee loyalty and the demographic variables. (Age, gender marital status, education qualification, experience in the organisation, income level, designation.

- To provide necessary suggestions to the pump manufacturing organisations in this regard.

\section{RESEARCH METHODOLOGY}

Data collection: Data for the research was collected through primary data (questionnaire \& Interview method) And Secondary articles from various web sources, articles, journals.

Sampling Method: Convenience sampling method is used by the researcher to collect the data from the respondents

Sample Size: 300 employees from pump manufacturing Industry

\section{Statistical Technique: Simple Percentage Analysis}

\section{Pilot Study}

The pilot study was carried out to validate the questionnaire and to confirm the feasibility of the study. For this purpose data collected from the sample of 100 respondents were tested using Cronbach's alpha methods. The pilot study was conducted and the respondents took 15-20 minutes to fill up the questionnaire.

\section{Validity Of The Questionnaire}

The questionnaire validity check was by some experts working in pump industry and also by some academic professionals in this field. This was done with an Aim to check and verify the items of the questionnaire and also whether the scale items represent the proposed domains or concepts in the questionnaire are intended measure of the study. After the validity check of the questionnaire, further analysis and reliability test was carried out using SPSS 20

\section{Reliability of the Pilot Study-Table-I}

\begin{tabular}{|r|r|}
\multicolumn{2}{|c|}{ Reliability Statistics } \\
\begin{tabular}{|r|r|}
\hline CRONBACH'S ALPHA & \multicolumn{1}{|c|}{ NO OF ITEMS } \\
\hline .836 & 72 \\
\hline
\end{tabular}
\end{tabular}

The questionnaire validity check was by some experts working in pump industry and also by some academic professionals in this field. This was done with an Aim to check and verify the items of the questionnaire and also whether the scale items represent the proposed domains or concepts in the questionnaire are intended measure of the study. After the validity check of the questionnaire, further analysis and reliability test was carried out using SPSS 20.

\section{PERCENTAGE ANALYSIS}

The researcher used percentage Analysis to find out the demographic information of the respondents .The Demographic variables included in the Study are Age of the respondents Marital Status, Educational qualification, income level, designation and experience in the current organization. Percentage Analysis is used by the researcher to create the frequency distribution of the collected data and to understand the responses of the respondents in a better way. The collected data of the research are represented in the form of table The Formula used for percentage Analysis

Percentage

$=$ No. of Respondents response for the questions

Total sample population of the study

Table -I Descriptive Statistics for Demographic Variables

\begin{tabular}{|c|c|c|c|}
\hline \multirow[b]{4}{*}{ Age } & \multicolumn{2}{|c|}{ Frequency } & \multirow{2}{*}{$\begin{array}{c}\text { Percentage } \\
62.00 \% \\
\end{array}$} \\
\hline & $21-39$ & 186 & \\
\hline & $40-59$ & 103 & $34.30 \%$ \\
\hline & $60-70$ & 11 & $3.70 \%$ \\
\hline \multirow[b]{2}{*}{ Gender } & Male & 207 & $69.00 \%$ \\
\hline & Female & 93 & $31.00 \%$ \\
\hline \multirow{4}{*}{$\begin{array}{c}\text { Education } \\
\text { al } \\
\text { Qualificati } \\
\text { on } \\
\end{array}$} & Diploma holder & 84 & $28.00 \%$ \\
\hline & Bachelors degree & 103 & $34.30 \%$ \\
\hline & Masters degree & 59 & $19.70 \%$ \\
\hline & Others & 54 & $18.00 \%$ \\
\hline \multirow{4}{*}{$\begin{array}{c}\text { Monthly } \\
\text { Income }\end{array}$} & $15000-25000$ & 84 & $57.00 \%$ \\
\hline & $25000-50000$ & 103 & $27.00 \%$ \\
\hline & 50000-75000 & 59 & $9.00 \%$ \\
\hline & More than 75000 & 21 & $7.00 \%$ \\
\hline \multirow{5}{*}{$\begin{array}{c}\text { Experience } \\
\text { In The } \\
\text { Current } \\
\text { Organisati } \\
\text { on }\end{array}$} & less than one year & 56 & $18.70 \%$ \\
\hline & $1-5$ years & 110 & $36.70 \%$ \\
\hline & 6-10 years & 79 & $26.30 \%$ \\
\hline & 10 plus years & 55 & $18.30 \%$ \\
\hline & TOTAL 300 & & $100 \%$ \\
\hline
\end{tabular}

Source: Primary Data

The Table 1 Above illustrates the following Interpretations

- The respondents of age group 21-29 are 62\% and the other respondents are 40-49 age are 34\%. Young employee's ratio is more when compared to the other age group of respondent's .Middle group age people between 40-49 are moderate and people Above 60+ of age is very less.

- The Male employees are more when compared to female employees . The male employees are around $69 \%$ while the female employees are $31 \%$.

- the UG Graduates and diploma degree holders are more when compared to other educational degrees .Bachelors degree holders are around 34\%,Diploma Holders are 28\% while master degree Holders are $20 \%$.Other degree is very less about $18 \%$.

- The majority of the people in the pump manufacturing Sectors falls under the income level 15000-50000 and above 50000-75000 is less. The employees are working in the current organization is having 5-10 years in the organization and less than one year is very less which is around $19 \%$ 
Table -III Descriptive Statistics for Working Environment

\begin{tabular}{|c|c|c|c|c|c|c|c|}
\hline \multirow[b]{2}{*}{ Variables } & \multicolumn{7}{|c|}{$\begin{array}{c}\text { FREQUENCIES } \\
\text { Number Of Respondents Total Values }\end{array}$} \\
\hline & $S D A$ & $D A$ & $N$ & $\boldsymbol{A}$ & $S A$ & Mean & Std.d \\
\hline WE1 & 0 & 16 & 6 & 100 & 178 & 4.466 & 0.781 \\
\hline WE2 & 0 & 22 & 79 & 95 & 104 & 3.936 & 0.949 \\
\hline WE3 & 0 & 18 & 44 & 148 & 90 & 4.033 & 0.829 \\
\hline WE4 & 2 & 7 & 22 & 138 & 131 & 4.296 & 0.759 \\
\hline WE5 & 0 & 18 & 36 & 127 & 119 & 4.156 & 0.857 \\
\hline WE6 & 0 & 25 & 63 & 139 & 73 & 3.866 & 0.878 \\
\hline
\end{tabular}

Source: Primary data Computed

\section{Interpretations}

From the above table III The respondents are satisfied with the working hours illustrated by the highest mean value $\mathrm{M}=$ 4.4667 of WE1 and the satisfied percentage of respondents rate is $59.3 \%$ but there is a lower mean value $\mathrm{M}=3.8667$ for WE8 in which $46.3 \%$ of respondents agreed that there is a healthy work life balance. In terms of Working environment there are six Items in which most of the respondents expressed high level of satisfaction.

Table -IV Descriptive Statistics for Relationship with superiors

\begin{tabular}{|c|c|c|c|c|c|c|c|}
\hline \multirow{2}{*}{ Variables } & \multicolumn{7}{|c|}{ Number Of Respondents Total Values } \\
\cline { 2 - 8 } & SDA & DA & $\boldsymbol{N}$ & $\boldsymbol{A}$ & $\boldsymbol{S A}$ & Mean & Std.d \\
\hline & & & & & & & \\
RS1 & 0 & 27 & 26 & 133 & 114 & 4.1133 & 0.90363 \\
\hline RS2 & 0 & 19 & 15 & 174 & 92 & 4.13 & 0.77142 \\
\hline RS3 & 7 & 0 & 11 & 176 & 106 & 4.2467 & 0.7355 \\
\hline & & & & & & & \\
RS4 & 12 & 17 & 28 & 128 & 115 & 4.0567 & 1.0313 \\
\hline & & & & & & & \\
RS5 & 5 & 17 & 7 & 169 & 102 & 4.1533 & 0.84787 \\
\hline & & & & & & & \\
RS6 & 0 & 0 & 40 & 114 & 146 & 4.3533 & 0.70485 \\
\hline & & & & & & & \\
RS7 & 0 & 0 & 12 & 156 & 132 & 4.4 & 0.56663 \\
\hline
\end{tabular}

Interpretations

From the table IV In terms of relationship with superiors there are 7 items the highest mean value is found for RS7 " A cordial working relationship with my superiors has helped to continue the services in this organisation $M=4.40$ with Std.Deviation of 0.5663 . Overall there is low disagreement response in this variable .Most of the respondents agreed there is a good relationship with superiors in the respective organisations

Table -V Descriptive Statistics for Relationship with Collegues

\begin{tabular}{|l|c|c|c|c|c|c|c|}
\hline \multirow{4}{*}{$\begin{array}{c}\text { FREQUENCIES } \\
\text { Variable } \\
\text { s }\end{array}$} & \multicolumn{7}{|c|}{ Number Of Respondents Total Values } \\
\cline { 2 - 7 } & $S D A$ & $D A$ & $N$ & $A$ & $S A$ & Mean & Std.d \\
\hline
\end{tabular}

\begin{tabular}{|c|c|c|c|c|c|c|c|} 
RC1 & 16 & 0 & 16 & 105 & 163 & 4.33 & $\begin{array}{c}0.985 \\
4\end{array}$ \\
\hline $\mathbf{R C} 2$ & 12 & 0 & 18 & 150 & 120 & 4.22 & $\begin{array}{c}0.879 \\
8\end{array}$ \\
\hline $\mathbf{R C 3}$ & 0 & 7 & 65 & 126 & 102 & 4.076 & $\begin{array}{c}0.803 \\
9\end{array}$ \\
\hline $\mathbf{R C} 4$ & 0 & 7 & 14 & 213 & 66 & 4.126 & $\begin{array}{c}0.587 \\
4\end{array}$ \\
\hline $\mathbf{R C 5}$ & 0 & 2 & 37 & 182 & 79 & 4.126 & $\begin{array}{c}0.631 \\
3\end{array}$ \\
\hline RC6 & 0 & 7 & 37 & 125 & 131 & 4.266 & $\begin{array}{c}0.764 \\
3\end{array}$ \\
\hline RC7 & 0 & 9 & 25 & 132 & 134 & 4.303 & $\begin{array}{c}0.748 \\
2\end{array}$ \\
\hline
\end{tabular}

\section{Source: Primary data Computed}

Interpretations

From the table V it is found that the variable "There is a harmonious relationship among the employees, across the hierarchies in the organization as well as in my department illustrated by the highest mean value $\mathrm{M}=4.3300$ of $\mathrm{RC} 1$ and the satisfied percentage of respondents rate is $54.3 \%$ In terms relationship with colleagues there are seven items in which most of the respondents expressed high level of satisfaction.

Table -VI Descriptive Statistics -Motivation\&Recognition

\begin{tabular}{|c|c|c|c|c|c|c|c|}
\hline \multirow{2}{*}{$\begin{array}{l}\text { Variabl } \\
\text { e }\end{array}$} & \multicolumn{7}{|c|}{$\begin{array}{c}\text { FREQUENCIES } \\
\text { Number Of Respondents Total Values }\end{array}$} \\
\hline & $S D A$ & $D A$ & $N$ & $A$ & $S A$ & Mean & Std.d \\
\hline MR1 & 12 & 2 & 5 & 170 & 111 & 4.22 & $\begin{array}{c}0.8528 \\
5 \\
\end{array}$ \\
\hline MR2 & 7 & 17 & 48 & 164 & 64 & 3.87 & $\begin{array}{c}0.8920 \\
5 \\
\end{array}$ \\
\hline MR3 & 7 & 50 & 26 & 124 & 93 & 3.82 & 1.1158 \\
\hline MR4 & 7 & 35 & 54 & 160 & 44 & 3.66 & $\begin{array}{c}0.9449 \\
7 \\
\end{array}$ \\
\hline MR5 & 7 & 49 & 67 & 80 & 97 & 3.7 & 1.1517 \\
\hline MR6 & 4 & 7 & 55 & 183 & 51 & 3.9 & $\begin{array}{c}0.7473 \\
5 \\
\end{array}$ \\
\hline MR7 & 0 & 5 & 58 & 171 & 66 & 3.99 & $\begin{array}{c}0.6939 \\
5 \\
\end{array}$ \\
\hline MR8 & 0 & 7 & 13 & 180 & 100 & 4.24 & 0.642 \\
\hline MR9 & 7 & 20 & 59 & 105 & 109 & 3.96 & 1.0192 \\
\hline MR10 & 8 & 77 & 13 & 110 & 92 & 3.67 & 1.2299 \\
\hline MR11 & 37 & 81 & 46 & 98 & 38 & 3.06 & 1.2641 \\
\hline MR12 & 56 & 82 & 48 & 100 & 14 & 2.78 & 1.2233 \\
\hline MR13 & 0 & 2 & 61 & 132 & 105 & 4.13 & $\begin{array}{c}0.7510 \\
7 \\
\end{array}$ \\
\hline MR14 & 13 & 11 & 58 & 167 & 51 & 3.77 & $\begin{array}{c}0.9227 \\
5\end{array}$ \\
\hline MR15 & 2 & 0 & 34 & 163 & 101 & 4.2 & $\begin{array}{c}0.6857 \\
3 \\
\end{array}$ \\
\hline MR16 & 0 & 11 & 57 & 152 & 80 & 4 & $\begin{array}{c}0.7780 \\
4 \\
\end{array}$ \\
\hline
\end{tabular}

Source -Primary Data

\section{Interpretations}

From the above table VI it is found that the variable MR8 "Performance appraisal improves my performance is illustrated by the highest mean value $\mathrm{M}=4.2433$ of $\mathrm{RC} 1$ with std deviation .64200 and the satisfied percentage of respondents rate is $60.0 \%$. The variable MR12 "Do you feel unappreciated and ignored in the work you do"illustrated the lowest mean value $\mathrm{M}=2.7800 \quad$ with 


\section{Antecedents of Employee Loyalty With Reference To Job Satisfaction in Pump Manufacturing Industries-Coimbatore City}

std.deviation 1.22335 and the respondents agreed with $33.3 \%$ and disagreed with $27.3 \%$

Table-VII Descriptive Statistics -Welfare Facilities Interpretation:

\begin{tabular}{|c|r|r|r|r|r|r|r|}
\hline & \multicolumn{7}{|c|}{ FREQUENCIES } \\
\cline { 2 - 8 } & \multicolumn{7}{|c|}{ Number Of Respondents Total Values } \\
\cline { 2 - 8 } Variable & $\boldsymbol{S} \boldsymbol{D A}$ & $\boldsymbol{D A}$ & $\boldsymbol{N}$ & $\boldsymbol{A}$ & $\boldsymbol{S A}$ & $\begin{array}{l}\text { Mea } \\
\text { n }\end{array}$ & Std.d \\
\hline WR1 & 38 & 120 & 42 & 74 & 26 & 2.76 & 1.204 \\
\hline WR2 & 37 & 116 & 36 & 91 & 20 & 2.8 & 1.189 \\
\hline WR3 & 15 & 113 & 45 & 102 & 25 & 3.03 & 1.189 \\
\hline WR4 & 0 & 13 & 96 & 140 & 51 & 3.76 & $\begin{array}{c}0.780 \\
6\end{array}$ \\
\hline
\end{tabular}

From the table VII it is found that the variable WEL 1 The mean value is $\mathrm{M}=3.763$ with std.deviation 1.2043 .In welfare facilities the disagreement response is about $40 \%$ from the respondents with the lower mean score $\mathrm{M}=2.766$ with std.deviation 1.2043.

Table -VIII Descriptive Statistics -Salary System

\section{Source :Primary Data}

\begin{tabular}{|c|c|c|c|c|c|c|c|}
\hline \multirow[b]{2}{*}{ Variables } & \multicolumn{7}{|c|}{$\begin{array}{c}\text { FREQUENCIES } \\
\text { Number Of Respondents Total Values }\end{array}$} \\
\hline & $S D A$ & $D A$ & $N$ & $A$ & $S A$ & $\begin{array}{l}\text { Mea } \\
\mathrm{n} \\
\end{array}$ & Std.d \\
\hline SS1 & 0 & 11 & 62 & 155 & 72 & 3.96 & 0.77 \\
\hline SS2 & 0 & 34 & 66 & 145 & 55 & 3.73 & $\begin{array}{c}0.88 \\
8\end{array}$ \\
\hline SS3 & 0 & 53 & 70 & 124 & 53 & 3.59 & $\begin{array}{c}0.97 \\
5 \\
\end{array}$ \\
\hline SS4 & 20 & 28 & 37 & 163 & 52 & 3.66 & 1.07 \\
\hline SS5 & 7 & 27 & 61 & 124 & 81 & 3.81 & 1 \\
\hline
\end{tabular}

\section{Interpretation:}

From the above table VIII it is found that the variable "Am getting a equitable salary in this organisation SS1 M= 3.96 with std.deviation .770 . In terms of salary system there are 5 items in which most of the respondents agreed that they are satisfied with the salary system

Table-IX Descriptive Statistics -Management Effectiveness

\begin{tabular}{|c|c|c|c|c|c|c|c|}
\hline \multirow[b]{2}{*}{ Variables } & \multicolumn{7}{|c|}{$\begin{array}{c}\text { FREQUENCIES } \\
\text { Number Of Respondents Total Values }\end{array}$} \\
\hline & $S D A$ & $D A$ & $N$ & $A$ & $S A$ & Mean & Std.d \\
\hline ME1 & 4 & 14 & 24 & 147 & 111 & 4.156 & 0.857 \\
\hline ME2 & 0 & 18 & 20 & 166 & 96 & 4.133 & $\begin{array}{c}0.781 \\
6\end{array}$ \\
\hline ME3 & 0 & 3 & 20 & 158 & 119 & 4.31 & $\begin{array}{c}0.639 \\
2\end{array}$ \\
\hline ME4 & 3 & 14 & 41 & 168 & 74 & 3.986 & $\begin{array}{c}0.813 \\
6\end{array}$ \\
\hline ME5 & 10 & 0 & 28 & 107 & 155 & 4.323 & $\begin{array}{c}0.898 \\
9\end{array}$ \\
\hline ME6 & 0 & 30 & 10 & 154 & 106 & 4.12 & $\begin{array}{c}0.880 \\
2 \\
\end{array}$ \\
\hline ME7 & 7 & 2 & 13 & 127 & 151 & 4.376 & $\begin{array}{c}0.802 \\
2\end{array}$ \\
\hline ME8 & 10 & 14 & 27 & 161 & 88 & 4.01 & $\begin{array}{c}0.934 \\
2 \\
\end{array}$ \\
\hline ME9 & 3 & 15 & 61 & 92 & 129 & 4.096 & $\begin{array}{c}0.957 \\
6\end{array}$ \\
\hline ME10 & 7 & 8 & 18 & 145 & 122 & 4.223 & 0.857 \\
\hline
\end{tabular}

\begin{tabular}{|r|r|r|r|r|r|r|c|} 
& & & & & & & 8 \\
\hline ME11 & 7 & 8 & 6 & 159 & 120 & 4.256 & $\begin{array}{c}3 \\
3\end{array}$ \\
\hline ME12 & 5 & 10 & 36 & 155 & 94 & 4.076 & $\begin{array}{c}0.844 \\
4\end{array}$ \\
\hline ME13 & 16 & 4 & 40 & 114 & 126 & 4.1 & 1.039 \\
\hline
\end{tabular}

Source: Primary Data

\section{Interpretation:}

From the table IX it is found that the variable ME7 1 "I am satisfied with the grievance handling procedures of the organization "the mean value is $\mathrm{M}=4.3767$ and std.deviation 0.80225. There are 13 items in this construct and the satisfaction level is high in this construct.

Table -X Descriptive Statistics - Employee Loyalty

Source :Primary Data

\begin{tabular}{|c|c|c|c|c|c|c|c|}
\hline \multirow[b]{2}{*}{ Variables } & \multicolumn{7}{|c|}{$\begin{array}{c}\text { FREQUENCIES } \\
\text { Number Of Respondents Total Values }\end{array}$} \\
\hline & $S D A$ & $D A$ & $N$ & $A$ & $S A$ & Mean & Std.d \\
\hline EL1 & 23 & 10 & 40 & 124 & 103 & 3.913 & 1.138 \\
\hline EL2 & 10 & 31 & 41 & 120 & 98 & 3.883 & 1.08 \\
\hline EL3 & 15 & 37 & 21 & 163 & 64 & 3.746 & 1.079 \\
\hline EL4 & 0 & 11 & 20 & 161 & 108 & 4.22 & $\begin{array}{c}0.725 \\
7\end{array}$ \\
\hline EL5 & 13 & 11 & 56 & 193 & 27 & 3.7 & $\begin{array}{c}0.851 \\
9\end{array}$ \\
\hline EL6 & 17 & 47 & 35 & 89 & 112 & 3.773 & 1.257 \\
\hline EL7 & 22 & 58 & 43 & 120 & 57 & 3.44 & 1.207 \\
\hline EL8 & 46 & 119 & 0 & 102 & 33 & 2.97 & 1.339 \\
\hline EL9 & 64 & 30 & 46 & 86 & 74 & 3.253 & 1.473 \\
\hline EL10 & 43 & 32 & 29 & 93 & 103 & 3.603 & 1.416 \\
\hline EL11 & 25 & 16 & 39 & 148 & 72 & 3.753 & 1.129 \\
\hline
\end{tabular}

\section{Interpretation:}

From the above table $\mathrm{X}$ it is found that the variable EL4 the mean value is $M=4.2200$ and std.deviation .72573 . Most of the respondents agreed with $53.7 \%$ that they cannot be more attached to any other organisation. The variable EL8 "I am afraid that there are too little options available for me" indicates low mean value $\mathrm{M}=2.97$ and about $39.7 \%$ respondents disagreed with the statement.

\section{FINDING OF THE STUDY}

- Young employee's ratio is more when compared to the other age group of respondent's .Middle group age people are moderate in numbers. This shows that there is more job opportunity for the people in the Pump manufacturing sectors in Coimbatore

- The Male employees are more when compared to female employees .The male employees are around $69 \%$ while the female employees are 31\%.Most of the Industry for some units the organisation prefers only male employees

- The UG Graduates and diploma degree holders are more when compared to other educational degrees.

The employment is given to all levels based on education.

- The majority of the people in the pump manufacturing Sectors falls under the income level 15000-50000 and above 50000-75000 is less. Hence it 
is understood that the pump industry salary varies with the level of the pump industry such as small scale, medium and large Scale and with the number of working employees in the organization.

- The employees are working in the current organization is having 5-10 years in the organization and less than one year is very less which is around $19 \%$.

- The respondents are satisfied with the working is $59.3 \%$.Most of the respondents expressed high level of satisfaction.

- The respondents are satisfied the relation with the supervisor .The satisfied percentage of respondents rate is $54.3 \%$

- $60.0 \%$ of respondents are satisfied with the appraisal system but some employees expressed their disagreement that sometimes their work is not getting recognized and this needs to be concentrated by the management

- $51 \%$ of the respondents are satisfied with the salary system of the organisation. But the neutral response rate is $21 \%$.It is understood that the respondents are not willing to give their response. This Indicates that management should take proper action on salary system.

- About $40 \%$ of the respondents expressed their disagreement response in the welfare facilities.

- Regarding the grievance handling procedures of the organization employees are satisfied .Hence it is understood that the organisation is concerned about the job satisfaction of the employees.

\section{LIMITATIONS OF THE STUDY}

Even though the study provide lot of insights it has certain limitations as follows

- The research was conducted with limited number of respondents with the Sample size 300.

- Some questionnaire was removed due to incomplete response from the respondents. This is also a major concern for the limited sample size.

- The researcher was unable to collect responses from various categories of employees .

- There are many factors influence employee loyalty but the study was limited with few factors

- The study was conducted only in pump manufacturing industry in Coimbatore region.

\section{CONCLUSION}

Satisfied and loyal employees create brand name and reputation to the organisation and are also play an important role in organisation performance. Hence it is very important for every organisation to have best retention strategies to retain knowledge and loyal workers. The employees in the pump manufacturing industries are happy to work for their organisation.

\section{REFERENCES}

1. Khuong, Ngoc Mai \& Tien, Diem Bui (2013), Factors influencing employee loyalty directly and indirectly through Job Satisfaction-A study of Banking Sector in Ho Chi Minh City, International Journal of Current Research and Academic Review, Vol.1 (4), Pp: 81-95

2. Ms. Chetna Pandey \& Mrs. Rajni Khare (2012), Impact Of Job Satisfaction And Organizational Commitment On Employee Loyalty, International Journal Of Social Science \& Interdisciplinary Research Vol.1 Issue 8, August 2012, ISSN 22773630
3. Karuppasamy Ramanathan \& ShanmugaSundaram Senthil ,2013) A Study on Role of Employee Loyalty in Quality Service of Equipment Rental Business Life Science Journal 2013; 10(9s):221-229] (ISSN 1097-8135)

4. Seema Mehta,Tarika Singh, S.S. Bhakar, Brajesh Sinha,(2010) Employee Loyalty towards Organization -A study of Academician International Journal of Business Management and Economic Research (IJBMER) Vol 1(1),2010,98-108(ISSN:2229-6247)

5. Kiruthiga.V \& Magesh.R (2015) "Rouse Employee Loyalty Through Job Satisfaction" Australian Journal of Basic and Applied Sciences, 9(10) Special 2015, Pages: 273-280, ISSN:1991-8178

6. Web article "Tips to Improve Employee Loyalty, by Susan E DeFranzo-Marketing Manager, U.S. at Snap Surveys, (Web source: https://www.snapsurveys.com/blog/tips-improve-employee-loyalty-pa $\underline{\mathrm{rt}-1 /}$

7. Web article "Tips to Improve Employee Loyalty, by Susan E. DeFranzo-Marketing Manager, U.S. at Snap Surveys, (Web source: https://www.snapsurveys.com/blog/tips-improve-employee-loyalty-pa $\underline{\mathrm{rt}-1 /}$ 